\title{
PELATIHAN PEMBUATAN MODUL UNTUK MENINGKATKAN KOMPETENSI GURU SMKN 4 SURAKARTA
}

Alfonsa Maria Sofia Hapsari, S.Si, M.M, Srianto, S.Si., M.Sc

Pendidikan Teknologi Informasi

Universitas Slamet Riyadi

Proses pembelajaran merupakan suatu rangkaian sistem dimana didalamnya terdapat beberapa komponen yang saling berkaitan satu dengan yang lainnya. Komponen tersebut adalah siswa, guru, lingkungan serta sarana (media) yang mendukung proses pembelajaran tersebut. Guru merupakan fasilitator dalam suatu proses pembelajaran. Hal ini sejalan dengan bentuk pembelajaran yang menggunakan pendekatan "Discovery" dan "inquiri". Pada pendekatan ini guru harus menyediakan sumber belajar yang diperlukan siswa untuk melakukan proses inquiri (menemukan), guru sendiri tidak akan mampu memberikan semua pengetahuan kepada siswa (Moh. Amin: 1987). Salah satu bentuk sumber belajar adalah modul yang dapat digunakan oleh siswa dalam proses pembelajaran. Apabila sumber belajar dibuat sendiri oleh guru, maka materinya akan disesuaikan dengan tingkat permasalahan yang ada di sekitar sekolah. Hal ini dikarenakan guru lebih tahu dan paham mengenai situasi dan kemampuan siswa.

Modul yang dikembangkan oleh guru harus memuat konsep-konsep penting yang akan dipelajari oleh siswa. Belajar konsep merupakan hasil utama pendidikan (Ratna Wilis, 1996: 79). Konsep-konsep merupakan dasar bagi prosesproses mental yang lebih tinggi untuk merumuskan prinsip-prinsip dan generalisasi-generalisasi. Untuk memecahkan masalah, seseorang siswa harus mengetahui aturan-aturan yang relevan, dan aturan ini didasarkan pada konsepkonsep yang diperolehnya.

Moh Amin (1987: 15), ber pendapat bahwa konsep adalah gagasan atau ide berdasarkan pengalaman yang relevan dan yang dapat digeneralisasikan. Menurut Suharyanto (2004: 3), konsep adalah ide atau gagasan yang 
menghubungkan beberapa fakta. Suatu konsep menggambarkan mata rantai antara beberapa fakta yang berhubungan. Untuk memperoleh konsep umumnya memerlukan kerja dengan objek nyata, eksplorasi, perolehan fakta, dan manipulasi ide sehingga memperoleh lebih dari sekedar ingatan. Semua konsep bersama membentuk semacam jaringan pengetahuan di dalam kepala manusia. Semakin lengkap, terpadu, tepat dan kuat hubungan antara konsep-konsep dalam kepala seseorang, semakin pandai orang itu. Keahlian seseorang dalam suatu bidang studi tergantung lengkapnya jaringan konsep di dalam kepalanya (Euwe Van den Berg,1997: 80).

Pengembangan modul pada dasarnya serupa dengan kegiatan menulis. Untuk membuat bahan ajar lebih mudah dipahami oleh si pemakai (siswa) maka diperlukan kemampuan guru dalam bidang tata tulis termasuk didalamnya kemampuan dalam bidang membangun paragraf yang baik. Sebuah buku tak mungkin baik jika paragrafnya tidak disusun dengan baik. Paragraf yang tidak jelas susunannya akan menyulitkan pembaca untuk menangkap pikiran penulis (Adjat Sakri: 1992). Akibatnya konsep, ide/gagasan dalam buku/bahan ajar tersebut tidak dapat dipahami oleh si pembaca. Selain mengenai pola penyusunan paragraf ada faktor lain yang juga memegang peranan penting dalam penulisan bahan ajar, yaitu penggunaan ejaan yang benar. Adanya penggunaan ejaan yang tepat dalam penulisan bahan ajar akan membantu si pembaca lebih mudah memahami makna bahan ajar tersebut (Adjat Sakri: 1994). Untuk membantu guru lebih mudah memahami cara menyusun dan mengembangkan bahan ajar khususnya sains (fisika), maka pengetahuan mengenai tata cara penulisan dan penyusunan bahan ajar merupakan syarat awal yang harus terpenuhi.

\section{ANALISIS SITUASI}

Proses pembelajaran merupakan rangkaian beberapa sistem yang saling berkaitan satu sama lainnya. Apabila salah satu sistem tidak dapat berfungsi maka sistem tidak dapat bekerja secara optimal. Proses pembelajaran akan lebih optimal jika dapat memanfaatkan media yang ada di sekitar kita. Penggunaan media dalam proses pembelajaran diharapkan dapat membantu guru agar lebih mudah dalam mengajarkan materi kepada para siswa. Pembelajaran yang 
dilakukan selama ini cenderung kurang memanfaatkan media pembelajaran yang ada. Beberapa hal yang menyebabkan hal ini terjadi adalah masih adanya pandangan dari guru bahwa media pembelajaran merupakan sarana yang mahal dan sulit dibuat sendiri oleh guru. Salah satu media yang sering digunakan dalam proses pembelajaran di sekolah adalah media LKS (Lembar Kerja Siswa) dan diktat/modul pembelajaran. Oleh karena para guru pada umumnya memanfaatkan LKS (Lembar Kerja Siswa) atau diktat/modul pembelajaran yang diperoleh dari penerbit (bukan dibuat sendiri oleh guru) sehingga berakibat materi yang diberikan dalam LKS atau modul tersebut kurang sesuai dengan materi yang akan diajarkan oleh guru.

Kondisi di atas terjadi karena guru pada umumnya merasa kesulitan dalam mengembangkan media tersebut. Kemampuan guru dalam mengembangkan modul masih sangat rendah. Terdapat beberapa faktor yang menyebabkan hal ini terjadi. Pertama, belum dipahaminya cara pembuatan dan pengembangan modul oleh guru. Kedua, masih minimnya penyelenggaraan pelatihan tentang pembuatan/pengembangan bahan ajar/diktat oleh instansi yang terkait. Ketiga, belum diketahuinya manfaat menjadi penulis sebagai profesi alternatif selain sebagai tenaga pengajar oleh guru.

Peralihan kurikulum KBK ke kurikulum yang baru menuntut adanya kemampuan guru untuk dapat membuat dan mengembangkan sendiri bahan ajar maupun media yang sesuai dengan tingkat kompetensi yang ada di masing-masing sekolah. Pengembangan bahan ajar akan optimal jika si pembuat (pengembang) bahan ajar benar-benar mengetahui kondisi siswa yang akan menggunakan bahan ajar tersebut. Apabila kondisi ini dapat tercapai diharapkan siswa maupun guru akan lebih mudah berkolaborasi dalam mempelajari materi. Adanya kemampuan guru dalam mengembangkan modul secara tidak langsung akan meningkatkan life skill guru untuk meningkatkan kesejahteraan guru. Profesi sebagai penulis buku ajar dan profesi sebagai guru merupakan profesi yang saling mendukung satu dengan lainnya apalagi jika buku yang ditulis merupakan satu rumpun bidang ilmu. Adapun tujuan diselenggarakannya kegiatan pelatihan pelatihan pembuatan modul bagi guru-guru SMKN 4 Surakarta adalah sebagai berikut: 
1. Meningkatkan pengetahuan peserta pelatihan tentang konsep dasar, teori dan prinsip mengenai penulisan modul

2. Meningkatkan keterampilan peserta pelatihan dalam menulis modul

3. Meningkatkan motivasi peserta pelatihan untuk menulis modul

\section{TARGET DAN LUARAN}

Target dari kegiatan pengabdian masyarakat ini adalah 50 \% guru mampu membuat modul, sehingga peningkatan kualitas proses pembelajaran di sekolah dapat tercapai. Pemakaian media pembelajaran modul sangat membantu dalam kegiatan pembelajaran khususnya pada sekolah dasar sampai sekolah menengah. Perkembangan teknologi pendidikan juga dapat mendukung pembuatan media pembelajaran yang berkualitas sehingga dapat menguatkan pemahaman siswa terhadap konsep-konsep yang diajarkan, dan dapat meningkatkan minat belajar peserta didik.

Luaran pada kegiatan ini merupakan hasil yang ingin dicapai dari pengabdian masyarakat yaitu terealisasinya rencana kegiatan pengabdian masyarakat yaitu memberikan keterampilan penguasaan pembuatan modul oleh guru SMKN 4 Surakarta

\section{PELAKSANAAN KEGIATAN}

Sesuai dengan jadwal, metode dan rencana pelaksanaan program yang sudah ditentukan maka hasil yang diperoleh dalah kegiatan ini adalah sebagai berikut.

1. Peserta yang datang dan mengikuti kegiatan pelatihan sebanyak 26 orang dari 40 orang peserta yang diundang.

2. Komposisi peserta yang datang terdiri dari para guru di SMKN 4 Surakarta.

3. Berhasil dilatihkan beberapa keterampilan menyusun bahan ajar sehingga dapat digunakan sebagai alat bantu dalam pembelajaran.

4. Peserta yang selama ini hanya menggunakan LKS dan bahan ajar terbitan suatu penerbit tertentu menjadi termotivasi untuk menyusun sendiri dan mengembangkan bahan ajar yang sesuai dengan karakteristik tempat para peserta mengajar. 
5. Melalui diskusi yang dilaksanakan setelah pelatihan berlangsung menjadikan peserta paham akan hal-hal apa yang harus diperhatikan untuk menyusun bahan ajar dan mengembangkan sehingga dapat meningkatkan pengetahuan mereka.

Berdasarkan hasil evaluasi yang telah dilakukan, dapat diketahui bahwa sebagian besar peserta merasakan dampak positif dari kegiatan Tim Pengabdi. Pengetahuan untuk mengembangkan bahan ajar meningkat. Sekitar 80\% peserta secara aktif menanggapi positif keterampilan dan pengetahuan yang disampaikan oleh Tim Pengabdi.

\section{KESIMPULAN DAN SARAN}

Berdasarkan pengamatan terhadap proses kegiatan pengabdian masyarakat berupa pelatihan penulisan buku ajar (hand out) untuk meningkatkan kreativitas dan life skill guru dalam mengembangkan media pembelajaran bagi guru-guru diperoleh hasil sebagai berikut.

1. Guru-guru SMKN 4 Surakarta menjadi paham dan mengetahui cara penyusunan maupun pengembangan bahan ajar yang sesuai karakteristik materi

2. Wawasan mengenai peluang dikembangkannya profesi baru sebagai penulis buku ajar untuk jangka panjang semakin terbuka di kalangan para guru.

Program pengabdian mengenai penyusunan bahan ajar yang inovatif ini hendaknya dikembangkan pada tingkat simulasi dan uji coba di sekolah. Hal ini dimaksudkan untuk mengetahui respon pengguna (dalam hal ini sekolah, guru, dan siswa). 